\title{
TRTaKadeMi
}

ISSN 2149-9446 | Cilt 06 | Sayı 12 | Mayıs 2021 | Dijital Hayat ve Etik

\section{Anomi Kavramını İnternet Ortamlarındaki Kullanım Pratikleri Üzerinden Yeniden Düşünmek: Dijitanomi}

\author{
Sertaç KAYA* - Burhan KILIÇ**
}

\begin{abstract}
Öz
Bireylerin yaşam sürerken gerçekleştirdiği neredeyse tüm etkinlikler arttk dijital araçlar dolayımıyla sanal bir ortamda gerçekleşebilmektedir. Bu durum, dijital bir toplumun varlığından söz edebilmeyi de mümkün hâle getirmektedir. Bu çalışmada, Durkheim ve Merton'un "anomi" kavramı ile ilgili tanımlamaları ve açıklamaları ışı̆ında, dijital-sanal alanlarda varlık gösteren bireylerin gerçekleştirdiği etkinliklerin, teknolojinin hızına ulaşamayan yasal düzenlemelerin eksikliği nedeniyle dijital bir anomi durumuna yol açıp açmadığı incelenmektedir. İnternet kullanıcılarının gerçekleştirdiği kimi etkinliklerde yasal durum hakkında bilgi sahibi olmadıkları veya kendi amaçlarına erişmek adına yasal durumu çok fazla umursamadıkları düşünülmektedir. Ayrıca internet dolayımı ile dijital ortamda etkinlik gerçekleştiren kullanıcılar, maddi bir karşıık verilerek sahip olunabilecek eserlere ve içeriklere ücretsiz bir şekilde ulaşabilmekte (internet erişim ücreti hariç tutulduğunda), aslında yasal olmayan faaliyetler gerçekleştirebilmektedir (yasa dışı bahis oynamak, yasaklı cinsel içeriklere ulaşmak, film-dizi-müzik-pdf kitap indirmek vb.). Çalışmada bu etkinliklerin durumunun saptanması adına TÜiK'in (2018) yaptığı araştırmada interneti en yoğun olarak kullandığı tespit edilen 18-24 yaş aralığında bulunan, İstanbul'da ikamet eden, üniversite öğrencisi olan internet kullanıcılarına bir anket uygulanmıştır. Çalışmada nicel araşttrma deseni olan betimsel tarama içerisinde yer alan ve önemli bir veri toplama kaynağı olarak görüldüğünden dolayı anket tekniği kullanılmıştr. Hazırlanan anket, internet ortamında dağıtıImış ve kolayda örnekleme yoluyla veriler toplanmıştır. Çalışma sonucunda yasal düzenlemelerdeki yetersizlik ve yaptırımların caydırıcılı̆ııın az olması nedeniyle kullanıcıların telifli ürünlere ve içeriklere bedelsiz olarak ulaşmasının dijital anomiyi ortaya çıkardığı görülmüş ve bu durumu tanımlamak için "Dijitanomi-Digitanomie" kavramının kullanılması önerilmiştir.
\end{abstract}

Anahtar Kelimeler: Emile Durkheim, Robert Merton, Anomi, Dijital Anomi, Netizens

*Arş. Gör. İstanbul Aydın Üniversitesi, illetişim Fakültesi, Gazetecilik Bölümü, sertackaya1@aydin.edu.tr

**Arş. Gör. İstanbul Aydın Üniversitesi, liletişim Fakültesi, Radyo Televizyon ve Sinema Bölümü, burhankilic@aydin.edu.tr

\section{Araştırma Makalesi}

Geliş Tarihi: 10.03.2021

Kabul Tarihi: 24.05.2021 


\title{
TRTAKaDeMi
}

ISSN 2149-9446 | Volume 06 | Issue 12 | May 2021 |Digital Life and Ethics

\section{Rethinking the Concept of Anomie Over Usage Practices in Internet Media: Digitanomie}

\section{Sertaç KAYA - Burhan KILIÇ}

\begin{abstract}
Almost all the activities that individuals perform while living can now take place in a virtual environment through digital tools. This situation makes it possible to talk about the existence of a digital society. In this study, in the light of the definitions and explanations of Durkheim and Merton regarding the concept of "anomie", it is examined whether the activities performed by individuals who exist in digital-virtual areas cause a digital anomie state due to the lack of legal regulations that can not reach the speed of technology. It is considered that internet users do not have information about the legal situation in their activities or do not care too much about the legal situation in order to achieve their own purposes. Furthermore users who carry out activities in the virtual environment via the Internet, can access the works and content that can be owned by giving money, free of charge (excluding the internet access fee), and actually perform illegal activities in the virtual environment (placing illegal bets, accessing prohibited sexual content, downloading movies-series-music-pdfbooks, etc.). In the study, in order to determine the status of these activities, a survey study was applied to the internet users who are between the ages of 18-24, residing in Istanbul, who are university students, who are found to use the internet most intensively in the research conducted by TüiK (2018). The questionnaire technique was used in the study because it is included in the descriptive survey, which is a quantitative research design, and is seen as an important data collection resource. As a result of the study, it was seen that the users' access to copyrighted products and contents free of charge due to the insufficiency in legal regulations and the low deterrence of the sanctions caused digital anomie and it was suggested to use the concept of "DijitanomiDigitanomie" to define this situation.
\end{abstract}

Keywords: Emile Durkheim, Robert Merton, Anomie, Digital Anomie, Netizens

Research Paper

Recieved: 10.03 .2021

Accepted: 24.05.2021 


\section{Giriş}

Daniel Bell'in (1973) düşünce olarak temellerini atth̆̆ endüstri sonrası toplum olarak da bilinen enformasyon toplumu ile birlikte bireyler kentlerde toplanmış ve bu kentleri yoğunlaştırmışlardır. Tim Berners-Lee'nin www (World Wide Web) sistemini bulması ile birlikte internet dünya geneline yayılmış ve bunun yanında web 1.0 ile web 2.0 teknolojileri ortaya çıkmıştır. Ayrıca bu teknolojilerin bir getirisi olan sosyal medya platformlarının da varlığının etkisi ile bir sanal ortam olarak adlandırabileceğimiz alanlardaki kullanıcı sayısı zamanla yoğunlaşmıştır. Kentlerdeki nüfus yoğunluğunun zamanla artması ile internet ortamındaki kullanıcı sayısının zamanla artması arasında anlamlı bir benzerliğin bulunduğu düşünülmektedir.

Endüstri devriminin meydana getirdiğini söyleyebileceğimiz ve günümüzde de sürmekte olan hızlı değişim ve teknolojik gelişme nedeniyle sosyal ve kültürel yapıda, örgütlenme şekillerinde ve bunun sonucunda da değer sistemlerinde önemli dönüşümler yaşanmaktadır. Bu durum nedeniyle günümüz insanının ekonomik, sosyal, siyasal sistemlerdeki değişimlerin hızına kimi zaman yetişemediği bir dünyada yaşadığı söylenebilmektedir. Özellikle teknoloji alanında meydana gelen hızlı dönüşümler insanların yaşam tarzlarını olumlu olduğu kadar olumsuz yönlerden de etkilemektedir. Teknolojik yenilikler toplumların üstyapı ile altyapılarını, sosyal, kültürel düzenlerini farklılaştırmakta, bu durum da bireyin topluma ve kendi özüne uyum sağlamasını güçleştirmektedir. Sonuç olarak bireyin doğa ile çevresi ve içinde var olduğu toplum ile ilişkisinde sorunlar ortaya çıkmaktadır (Ofluoğlu ve Büyükyılmaz, 2008: 114).

Sassen (2017), zaman içinde insanların ve sosyal koşulların, teknolojilerin kullanımını karmaşık hâle dönüştürdüğünü ifade etmektedir. Bu durum, günlük hayatın belli gereklilikleriyle insanların teknoloji kullanım kültürlerinin ne şekilde bir araya gelebileceğinin kolayca öngörülememesine neden olmaktadır. Bu öngörü noksanlığı, internet üzerinden kullanıcıların ücret ödemeden telifli ürünleri elde edebilmesi ile daha farklı bir boyuta taşınmaktadır. Schneck (2010: 79-80) kimi ülkelerin bu durumu çözmek için adımlar atmasına rağmen alınan kararların çözüme varabilmesi için dünya çapında benzer girişimlerin olması gerektiğini ifade etmektedir. Aksi hâlde internetin, kuralların bulunmadığı "kopya cennetleri” ne dönüşeceğini, erişim sağlayan herkesin film ve müzik başta olmak üzere çeşitli ürünleri kopyalayabileceğini, dağıtabileceğini ve kendi kullanımı için indirebileceğini ifade etmektedir.

Endüstri toplumunda kentlerde yer alan nüfus yoğunluğunun yarattğı düzenleme yoksunluğundan doğan durumun bugün endüstri sonrası topluma karakterini veren 
ağlar alanında da yaşandığı düşünülmektedir. İnternet aracılı ortamlarda meydana gelen durumların nasıl ciddi sorunlara yol açabileceği artık günümüzde bilinmektedir. O nedenle sanal ortamları da günlük hayatımızda karşılaşt̆ğımız, duyu organlarımızla algıladığımız ortamlar gibi görebileceğimiz ve bu ortamları daha önce var olan kavramlar, teoriler, kuramlar ışığında ele alabileceğimiz düşünülmektedir. Gerçek hayatta var olan ve sosyoloji ile iletişim çalışmaları alanı içinde bulunan kavramlar zamanla dijital iletişim çalışmaları vasıtasıyla sanal alanlara uyarlanmış veya bu alanlara taşınmıştır. Literatüre göz atıldığında netizens (Hauben ve Hauben, 1998), siber suçlar (Jaishankar, 2011), siber-dijital toplum / ağ toplumu (Lindgren, 2007, Castells, 1996, 1997, 1998; Van Dijk, 1999), dijital gözetim (Lyon, 2001), dijital demokrasi (Hague ve Loader, 1999, Hacker ve Van Dijk, 2000, Hindman, 2009), dijital kimlik (Turkle, 1995; Papacharissi, 2010) gibi aslında reel dünyaya ait olan kavram, olgu veya olayların internet ortamına uyarlandığı görülmüştür. Bu çalışma ise sosyoloji ve iletişim çalışmaları alanının çalışma konuları içinde yer alan anomi kavramının internet ortamına uyarlanması noktasında var olduğu düşünülen bir boşluğun doldurulma gerekliliğinden doğmuştur.

Çalışmamızda "anomi” kavramı bugün bulunduğumuz teknoloji ve internet yoğun toplumda var olan durumu analiz etmek için kullanılmaktadır. Bu bağlamda Durkheim ve Merton'un "anomi” kavramlarını nasıl açıkladıklarına değinilecek, internetin yoğun kullanımı ile ortaya çıktığı düşünülen 'internet dolayımlı toplum'a geçiş süreci anlatılmaya çalışılacaktır. Ardından bu şekilde ifade edilen toplumun getirisi olarak düşünebileceğimiz "internet vatandaşı" anlamını içinde barındıran "netizens" kavramı açıklanarak "anomi" kavramının dijital ortama yansıması şeklinde düşünebileceğimiz "dijitanomi” kavramının kullanılması önerilecektir.

Çalışmada nicel araştırma deseni olan betimsel tarama içerisinde yer alan ve önemli bir veri toplama kaynağı olarak görüldüğünden dolayı anket tekniği kullanılmıştır. Betimsel tarama ile araştirmacı, bir gruptaki kişilerin, bir olgu veya olay hakkında görüş ve tutumları neticesinde elde ettiği verilerden olgu ve/veya olayların betimlemesini yapabilmektedir (Karakaya, 2012: 59). Bu çalışmada da 18-24 yaş aralığındaki internet kullanıcılarının internet ortamında gerçekleştirdiği faaliyetlerin, bu faaliyetleri düzenleyen yasaların eksikliği veya var olan düzenlemelerin yeterince bilinmemesi nedeniyle dijital ortamda bir anomiye neden olup olmadığı araştırılmaktadır.

Çalışmada var olduğu düşünülen dijital anomi durumunun saptanabilmesi adına bir anket gerçekleştirilerek sonuca varılmaya çalışılmıştır. Anket sorularının çalışmada ele alınan dijital ortamlardaki anomi durumunu ortaya çıkaracak biçimde oluşturulmasına özen gösterilmiştir. Bu bağlamda çalışmanın amacı kullanıcıların 
ücretli içeriklere ve ürünlere ne şekilde ulaştığını ve bu kullanım pratiklerinin yasal durumları hakkında bilgi sahibi olup olmadığını ölçümlemektir.

\section{Durkheim’a Göre Anomi Kavramı}

Anomi (anomie, anomy) bir toplumda var olan kuralların etkisiz hâle gelmesi, çöküntü, çatışma ya da karışıklığın meydana gelmesi durumunu belirten bir terimdir. Eski Yunan metinlerinde sıklıkla karşılaşılan anomi "yasasız" anlamını taşıyan "anomos" kelimesi ile ilişkilendirilmektedir. Kavram, çöküntü ve enkaza atıfta bulunan geniş çaplı ve çoğunlukla olumsuz manalar çağrıştıran bir biçimde kullanılagelmiştir (Marshall, 2005: 32).

Insanın varoluşunda meydana gelebilecek bir değişiklik, ani bir şekilde de olsa önceden bilinen bir şey de olsa, acıya sebebiyet verici bir kriz oluşturmaktadır. Bunun nedeni edinilmiş içgüdülere yönelik şiddet uygulaması ve ona direnç sunmasından kaynaklanmaktadır. Güzel beklentiler bizleri ilerlemeye özendirse de bütün bir geçmiş bizleri geride tutmaktadır. Bu yüzden zamanın bedenimizde sabit hâle getirdiği ve organize ettiği alışkanlıkları yok etmek zahmetli bir eylem olmaktadır (Durkheim, 1984: 186).

"The Division of Labour in Society (1984)" isimli çalışmasında Durkheim'ın sunmuş olduğu fikirler anominin sadece ekonomik düzensizlikle alakalı olduğunu belirten yaklaşımların yanlış olduğunu göstermektedir. Modern toplumlarda yürütülen çok sayıda faaliyetin ekonomi paydasında toplanabilmesi Durkheim'ın çalışmalarını neden bu paralelde yürüttüğünün sebeplerini göstermektedir. İş bölümünden kaynaklanan ortam, anominin incelenmesi adına bir kapı aralamaktadır.

Hayat şartları değiştiğinde, ihtiyaçları düzenleyen adımlar aynı şekilde devam edemeyip toplumsal kaynaklara göre yeniden kurgulanmaktadır. Hem insanların hem de nesnelerin kamuoyu tarafindan tekrardan sınıflandırılması için zamana ihtiyaç vardır. Serbest olan toplumsal kuvvetler, dengelerini tekrardan bulamadıkça tüm hepsinin değeri belirsiz kalacaktır. Bunun neticesinde toplumsal düzenlemelerin yokluğu hissedilecektir. Neyin olup olamayacağı, hangi isteklerin ve umutların haklı olup olmadığı, ölçüyü kaçıranların kimler olduğu bilinemez duruma gelmektedir. Bu durumun avantajlı hâle getirdiği sınıflar kontrol edilemeyen bir istekle sınırlarını bilememeye başlarlar. İstekler, arzular ve talepler en üst seviyelere ulaşmaktadır. Geleneksel kuralların işlevselliğini kaybettiği anda, kendilerine sunulan imkânların genişlemesi insanları daha sınır tanımaz hâle getirmektedir. Arzulara ve isteklere kuvvetli bir disiplin lazımken aksine başıbozuk bir durum meydana gelir; düzensizlik ve kuralsızlık, içinde bulunulan ortamda artmaktadır. Aşırılığa kaçmış isteklerin sonuçları ne olursa olsun bireyler doyuma ulaşama- 
maktadır. Çünkü isteklere sınırları aşmamaları yönünde herhangi bir telkinde bulunulmamaktadır. Düzenlemelerin zayıfladığı ortamda da mücadele daha çetin ve acılı olmaktadır. Ayrıca her ne kadar çözümsüz olsa da bolluğun artışının getirdiği ahlaksal tehlike göz ardı edilmemelidir (Durkheim, 2013: 256-258).

Durkheim'ın ilk anomi yaklaşımı, sosyal faaliyetler arasındaki ilişkileri yöneten bir kurallar bütününün yokluğuyla biçimlenmekteydi. Anomi teriminin tam olarak sosyo-psikolojik noktaya ulaşması Durkheim’ın “intihar (Suicide)” çalışmasına kadar gerçekleşmemiştir.

Durkheim, sapkın davranışta, sosyal entegrasyon ve sosyal değişimin etkili olduğunu belirtmektedir. Eğer toplumda hızlı bir değişim varsa bu durum, normlarda belirsizliğe ve devamında da anormalliklerin ortaya çıkmasına neden olacaktır. Normsuzluk hâli olarak tanımlanabilecek anomi, toplumun, içinde yaşayan bireylerin beklentilerini ve davranışlarını etkili bir biçimde düzenlemesindeki başarısızlığını ifade etmektedir. Amaçların düzenlenmesinde ortaya çıkan bozulmaların, normsuzluğu ve anormalliği tetiklediğini söylemektedir. Bu tarzdaki düzenleme yoksunlukları insanların isteklerini sınırsız hâle getirmekte ve sapmayı ortaya çıkarabilmektedir (Inderbitzin, Bates ve Gainey, 2016: 133).

Bir toplumsal işlev, ahlaki bir disiplin kurulamadan işlerlik kazanamamaktadır. Ahlaki bir disiplin kurulmadığı takdirde bireysel hırslardan geriye bir şey kalmamış olur ve bu hırslar doğal bir şekilde doyumsuz ve sınırsız olduklarından, düzene sokulmazlarsa kendi kendine düzene girmeyeceklerdir. Ayrıca, toplumun bütününü etkilemeye yönelik bir etkinlik türü, özel ahlaki sınırların dışına itilirse bunun sonucu bir anarşiyi meydana getirecektir. Böyle beliren güçler normal gelişim düzenlerinin nasıl olması gerektiğini bir daha kavrayamazlar. Çünkü bu güçlere durması gereken yeri gösterebilecek hiçbir şey bulunmamaktadır. Bu nedenle uyumsuz hareketler biçiminde mücadele etmeye, birbirlerini ezmeye, ortadan kaldırmaya, pasifize etmeye uğraşmaktadırlar. Şüphe yoktur ki güçlü olanlar zayıf olanları ezmeyi veya hiç yoksa bir egemen bağımlı ilişkisi içine sokmayı başarmaktadırlar (Durkheim, 2006: 55-56).

Toplumsal gruplar genişledikçe düzenlemelerin gereklilik durumu da artmaktadır. Çünkü grup bireylerinin sayısı azken birey ile toplum arasında var olan ayrım zayıf olmaktadır, böylece bütün ile parçayı birbirinden ayırt etmek zorlaşacaktır ve dolayısıyla bütünün çıkarına olanlar her grup üyesi tarafindan doğrudan benimsenecektir. Fakat toplumdaki üye sayısı genişledikçe farklılık da derinleşmeye başlamaktadır. Grup içerisinde yer alan bireyler genişleme ile birlikte toplumsal ufkun yalnızca küçük bir kesimine ulaşabilmektedir, dolayısıyla etkinliklerinin ko- 
lektif amaçlara uyması için neleri yapıp neleri yapmaması gerektiği ona kurallar ile aktarılmazsa eylemlerinin asosyal bir durum alması kaçınılmaz olacaktır (Durkheim, 2006: 60).

İnternetin kullanımının zamanla artışı ve internet ortamında bulunan bireylerin sayısının çoğalması ile birlikte Durkheim'ın burada belirttiği “düzenlemelerin gereklilik durumu" çalışmamız açısından önemini ortaya koymaktadır. Bugün geldiğimiz noktada interneti çeşitli amaçları için kullanan bireylerin neyin yasal neyin yasa dışı olduğu ile ilgili bir bilgilendirmeye sürekli bir biçimde gereksinimi olduğu düşünülmektedir.

\section{Merton'un Anomi Kavramına Yaklaşımı}

Merton, davranışlardaki sapmanın sosyokültürel nedenlerinden ilkinin, kültürel olarak belirtilen hedefler ve ilgi alanlarından oluştuğunu belirtmektedir. İkincisinin ise amaçlara varmak için kabul edilebilir durumları tanımlamak, düzenlemek ve kontrol etmek olduğunu ifade etmektedir. Tüm gruplar, hedeflerine varmak için kabul edilen ve gerekli işlemlerin ahlaki veya kurumsal düzenlemesiyle kendisinde var olan arzu ettiği hedef ölçeğini birleştirmektedir. Düzenleyici olarak bulunan normlar ve ahlaki mecburiyetler, teknik veya verimlilik normlarıyla her zaman denk düşmemektedir (Merton, 1938: 672-673).

Yasaklanmış davranışların (yolsuzluk, hırsızlık, dolandırıcılık, ahlaksızlık vb.) tamamı, başarı için gösterilen amaçlara vurgu, kurumsal olarak kendi yolundan ayrıldığında giderek yaygınlaşmaktadır (Merton, 1938: 675). Bu davranışların yaygınlaşmasının temelinde hedeflere ulaşmak için gidilen meşru yollardan sapma bulunmaktadır.

Toplumda yaşayan her birey için kabul edilen kültür değerlerine ulaşmak adına girilen mücadeledeki eksiklikler, başarıyı temsil eden maddi birikime yapılan kültürel göndermenin benimsenmesi ile ilgisi bulunduğu ölçüde, gösterilen antisosyal davranışların doğal karşılanmasına sebep olmaktadır. Amaca olduğundan fazla anlam yüklendiğinde ve bu amaca giden araçlara erişim sosyal yapı tarafindan kısıtlandığında, "Amaç, araçları meşrulaştırır." yaklaşımı ilke olarak benimsenmektedir. Bu yapı, kişilere kendilerine engel olarak gördükleri durumları ortadan kaldırması için baskı yaratmaktadır (Merton, 1938: 681-682). Merton, bu bağlamda amaç ve araç arasındaki koordinasyon eksikliğinin anomiye neden olduğunu ortaya koymaktadır.

Merton, başarı için bir şekilde oyunu kazanmanın, oyunu kurallarına uygun olarak kazanmanın önüne geçtiğini, net biçimde ortaya konulmasa da yasa dışılığın 
üzerine vurgu yapıldığını belirtmektedir. Amaçlara yapılan bu vurgu, oyuna dâhil olmanın önemini azaltarak bundan sağlanan tatmini ortadan kaldırmış ve sadece başarının tatmini getirdiği yeni bir durumun ortaya çıkmasına neden olmuştur (Merton, 1968: 190-191). Oyun neticesinde kazanç olarak gösterilen hedeflere ulaşmak önem kazandığında kurallar değerini yitirmekte, katılımcılar tarafindan onlara uymak mecburiyet taşımamaktadır. Oyun içinde olmak bir mana ifade etmemekte, yalnızca nihayete vardığında memnuniyet sağlamaktadır. Bu durum, kuralların ve normların işlevselliğini yitirmesine başarı için verilen mücadelede düzensizliğin ortaya çıkmasına neden olmaktadır.

Kısaca Merton, anominin düzenlenmemiş amaçlardan değil, kültürel amaçlarla bunlara ulaşmanın meşru yolları arasındaki yanlış ilişkilerden kaynaklandığını savunmaktadır (Inderbitzin, Bates ve Gainey, 2016: 134). Bu da Merton'un anomi yaklaşımının temelinde gayeler ve bunları gerçekleştirmek için başvurulan araçların birbiriyle bütünleşmemesinden, birbirlerinin tamamlayıcısı olmamasından ileri gelmektedir.

Kültürel yapı, organize normatif değerler üzerinden bir grup veya toplum içindeki bireylerin ortak davranışlarını yönetmektedir. Sosyal yapı ile anlatılmak istenen, grup veya toplumdaki kişilerin çeşitli biçimlerde içerisine girdiği organize sosyal ilişkiler kümesidir. Anomi, kültürel normlar ve amaçlarla toplumdaki bireylerin bunlarla uyumlu hareket etme durumlarındaki derin ayrılık oluştuğunda kültürel yapıda bir kırılma olarak ifade edilebilmektedir. Böyle bir durum ortaya çıktı̆ında kültürel değerler, değerlerin gösterdiği komutlarla ayrışan davranışların doğmasına yardımcı olabilmektedir. Sosyal yapının da kültürel değerleri zorlaması sonucunda toplumdaki belli statülere sahip kişilere uygun fiiller hızlıca mümkün kılınırken diğer kişiler için zor veya imkânsız olmaktadır (Merton, 1968: 217).

Merton, anomi durumuna karşı beş genel pozisyonun bulunduğunu savunmaktadır. Bunlardan ilki uyumdur (Conformity). Bu durumda olanlar konformist olarak adlandırılmaktadır ve bu kişiler kültürel başarı/zenginlik elde etme amacını kabul edip bunu meşru yollardan elde etmeye çalışmaktadırlar. Uyum, anomiye karşı sapkın olmayan tek adaptasyon olarak görülmektedir. Örnek olarak, üniversite öğrencilerinin iş edinmek ve mezun olup başarı elde etmek için çalışmaları verilmektedir. Yenilikçilik (Innovation), kültürel başarı/zenginlik elde etme amacını kabul edip bunu meşru olmayan yollardan gerçekleştirmeye çalışanların adaptasyonunu oluşturmaktadır. Yolsuzluk, hırsızlık ve uyuşturucu satıcılığı gibi eylemler bu kategoride bulunmaktadır. Ritüalizm (Ritualism), kültürel başarı/zenginlik elde etme amacından vazgeçen fakat geçinmek için meşru yolda kalmaya devam edenlerin kategorisidir. Yönetime ulaşma hedefi olmayan kendisini işine vermiş 
işçiler, ritüelciler olarak adlandırılmaktadır. Geri çekilme (Retreatism), kültürel başarı/zenginlik elde etme amacını da meşru yollarını da reddedenlerin bulunduğu kategoridir. Uyuşturucu bağımlıları ve evsizler bu kategoride bulunmaktadır. İsyan (Rebellion) ise kurallara uygun davranmayıp sistemi kendi isteğine göre biçimlendirmeye çalışan sapkınların bulunduğu kategoridir. Terörist gruplar, isyancıların en belirgin örneğini oluşturmaktadır (Inderbitzin, Bates ve Gainey, 2016: 134-136).

Durkheim'ın bakış açısı ile "anomi" toplumların mekanik dayanışma ile organik dayanışma arasında yaşadığı geçiş sürecinde ortaya çıkan bir durumken Merton'un bakış açısına göre araçların amaçlarla kesişmesi sonucunda ortaya çıkan bir durumdur. Yine Durkheim tarafindan anomi bir geçiş dönemi sorunu biçiminde ele alınmakta ve bu sorunun organik dayanışmanın kurumsallık kazanması ile birlikte ortadan kalkacağı belirtilmektedir. Merton'a göre ise anomi, bir geçiş dönemi sorunu olmaktan öte toplumsal yapılar ve kültürel değerlerin oluşturduğu baskılar tarafindan ortaya çıkmıştır (Marshall, 2005: 33).

\section{Internet Dolayımlı Topluma Geçiş}

Bilgisayarlar, mobil cihazlar, telekomünikasyon teknolojileri, internet ve sosyal medya; gündelik hayattaki dijitalleşmeyi arttrmakta, bireyler, toplumlar ve kültürler üzerinde etkili olmaktadır. İletişim kanallarının genişliği bizlere bilgi elde etmek, üretmek ve paylaşmak için zemin hazırlamaktadır. Tarih boyunca insanların iletişim ve etkileşim amacıyla ortaya koyduğu tüm ürünler, kişilerin ve grupların dünya ile kurdukları ilişkiyi ve toplumların, kültürlerin nasıl dönüştüğünü bizlere göstermektedir. Bugün ise teknolojik gelişmelerin ve bunların uygulanmasının arkasındaki temel mantık toplumlardaki değişim ve dönüşümleri tetiklemektedir.

Özellikle ekonomik başarıyı, eğitimi ve demokratik süreci birlikte etkileme kapasitesine sahip internetin hızlı büyüyüşü, birçok yoruma da ortam hazırlamıştır. Medya da halkın, internete ulaşmak için gereken araçların kullanılması konusunda ustalaşması gerektiğini ve bir “bilgi otobanı”nın gelişini düzenli olarak sunmuştur. Yetkili sesler ise "yeni bir düzen"i ilan etmek için yükselmiştir. Internet teknolojilerinin, özellikle geniş bant tabanlı olanların hızlı bir şekilde benimsenmesi önemli bir durumdur. Çünkü bu teknoloji, telefonları kapatmadığımız takdirde her zaman açık olabilmektedir. Kablosuz bağlantı ile birlikte kullanıcı her zaman ve mekânda ağ ile temas hâlindedir. Diğer bir deyişle sürekli bağlıdır (Webster, 2006: 10).

Birbiri ardına yapılan araştırmaların verdiği sonuçlar bize yerin altında, gökyüzünde, kucaklarımızda ve hatta ceplerimizde silikon, bakır, optik, fiber ve kablosuz 
altyapılar aracılığıyla akan yüksek oranda enformasyon ve bilgi hakkında önemli sonuçlar vermektedir. Birçok birey aslında oldukça iyi bir bağlantılılık hâlinde bulunmaktadır ve bu durum toplumdaki dijital araçlar yerine, giderek daha fazla dijital bir topluma sahip olduğumuz düşüncesini doğurmaktadır. Daha önceleri tekerlek, matbaa, buhar makinesi, telefon gibi icatların yaptğını bugün dijital medya, günümüz toplumuna damgasını vurarak gerçekleştirmektedir. Bunun yanı sıra, toplumdaki bireyler, bu teknolojileri kullanma, uyarlama ya da direnme yollarıyla yeni medyayı biçimlendirmeye daima katkı sağlamaktadır. Bugün, yaşamlarımızın, ilişkilerimizin, kültürümüzün ve sosyalliğimizin dijitalleştiği ve dijital süreçlerden etkilendiği bir çağda yani dijital bir toplumda yaşamaktayız (Lindgren, 2017: 3-7).

Dijital toplumun temelinde bilgisayar teknolojisi ve internet yer almaktadır. Dijital toplumda insanlar internet bağlantıları sağlayarak iletişim kurmakta, etkileşime girmekte ve ağlara bağlı olarak faaliyetlerini yürütmektedir. Dijitalleşmenin toplum ve kültür ile bütünleşmesi sonucunda ortaya dijital toplum çıkmaktadır.

Internet teknolojilerinin yaşamlarımızda kapladığı alan genişledikçe kimlik, ilişkiler, güvenlik ve daha temel alanlara kadar hayatın neredeyse her yönüyle ilgili anlayışımız değişmektedir. Teknolojinin etkililiği arttkça coğrafya, dil ve bilgiye erişim gibi değişkenlerin önünde uzun zamandır var olan engeller ortadan kalkmakta ve yeni bir insan yaratıcılığı potansiyeli yükselmektedir. Internetin kitlesel olarak kabul edilmesi, tarihteki en etkileyici sosyal, kültürel ve politik dönüşümlerden birini tetiklemekte ve bu değişim daha önceki dönemlerinden farklı olarak küresel nitelikte olmaktadır (Schmidt ve Cohen, 2013: 1-2).

Hangi perspektiften hangi disiplinden bakılırsa bakılsın internet teknolojileri; insanların iletişim biçimlerini, bilgiye erişimini, oyun oynama alışkanlıklarını, çalışma şekillerimizi, müziğe ve diğer medya içeriklerine ulaşmamızı yakın bir zaman içinde dramatik olarak değiştirmiştir. Dijital teknolojilerin bireylerin ve toplumların günlük hayatlarına nüfuz ettiği birçok farklı nokta bulunmaktadır. Çoğu insan taşınabilir hâle gelen dijital cihazların yardımıyla, ağlarla bağlantılı bir yaşam sürmektedir. Haber, bilgi, müzik, oyun, dizi ve filmlere dijital platformlar ve bunlara erişim sağlayan cihazlar üzerinden ulaşılabilmektedir. Bu teknolojiler bizlere yön vermekte ve kendimizi siber uzayda bulmamıza neden olmaktadır. Tüm bu yaşanan gelişmeler bizleri dijital toplumun birer ferdi hâline getirmektedir.

Bugün bilgisayarlar yalnızca bizler için bir şeyler gerçekleştirmekle kalmamakta, iş yapış şekillerimiz, düşünme biçimlerimiz ve daha birçok noktada yeniden üretim gerçekleştirmektedir. Bu cihazların ilk dönemlerinde durum böyle olmamak- 
la birlikte doğrudan etkiler yaşantımıza tamamıyla dâhil olduğunda ve birincil etkileri hissedilmeye başlandığında ortaya çıkmıştır. Bugün birçok insan siyasal, ekonomik, kültürel, sosyal veya duygusal deneyimler ve etkiler için bu araçlara yönelmektedir.

\subsection{Internet Yurttaşları: Netizens}

Hauben ve Hauben (1998), netin vatandaşları için netizen kavramını kullanmıştır. Vatandaş terimi, sosyal aidiyetin coğrafi ya da ulusal bir tanımı üzerinden hareket etmektedir. Oysa netizen, coğrafi düzlemde bir ortaklığı bulunmayan yeni sosyal üyeliği yansıtmaktadır. Ancak, bu kavramın çevrim içi olan herkesi kapsamadığını belirtmektedir. Netizenler olarak tabir ettiği kişilerin internete sadece hizmet için veya bireysel kazanç ve kâr amacıyla gelen kişiler olmadığını, aksine bu kişilerin interneti yenileyici ve kaynak hâline getirmek gayesiyle çaba sarf eden ve eylemde bulunma gerekliliğini idrak edenler olduğunu ifade etmektedir. Ayrıca netizenlerin diğer özelliklerini, ortaya yeni çıkan bu alanları iyi bir yer hâline getirmek isteyen, açık bir şekilde internette bulunanlar ve gösterişten uzak işlerde bulunanlar şeklinde sıralamaktadır.

Bunun yanı sıra yine Hauben ve Hauben (1998), netizenlerin diğer bireylerle etkileşime girerek bilgi ekleme ya da değiştirme işlevlerini gerçekleştirdiğini söylemektedir. Ağlardaki bilgi bu yönüyle sabit bir mal ya da kaynak olarak görülmemektedir. Sürekli olarak yeni eklemeler ve geliştirmeler ortaya çıkmaktadır. Böylece tüm netizenler dünya genelindeki bilgi deposunu sürekli biçimde genişletmektedir. Çünkü internetteki bilgi akışı yine bu alanda bulunan ve interneti kullanan kişiler tarafindan kontrol edilmektedir. İnternet, kişilere kontrol edebilecekleri bir ortam sağlamaktadır. Bu durum netizenler tarafindan gerçek hayattaki bilgilerin ve kaynakların internet ortamına aktarılması durumunu da beraberinde getirmektedir. Kontrolün sıkı bir şekilde gerçekleştirilemediği bu alanlarda kullanıcılar diledikleri içerikleri yayabilmekte, farklı kanalları internete entegre ederek üyelerin erişimine açabilmektedir. Çevrim içi olan herkes ilgi alanlarına göre kategorilenmiş içeriklere ve diğer çevrim içi üyelere ulaşabilmektedir. Böylece internet, halka açık hâle getirilmiş birçok verinin dijital deposu işlevi görmektedir.

Teknolojilerin ve internetin gelişimi arttıkça ve bireyleri bu gelişime uyum sağlamaya zorladıkça yaşamın, politikanın, ekonominin ve toplumun farklı yönlerini etkileme potansiyelinin ne kadar yüksek olduğu artık bilinmektedir. Çeşitli ülkelerdeki hükûmetler, vatandaşlara hükûmet bilgileri ve hizmetleri sunmak için interneti ve dünya çapında ağı (world wide web) kullanmaya başlamıştır. Bugün yaşamlarımızın hemen her yerinde görebileceğimiz e-uygulamalar ile e-yöneti- 
şim uygulamalarının on yıldan daha önce öngörüldüğü gibi şekillendiğini ve bir vatandaşın hayatını kolaylaştırdığını söyleyebilmek mümkündür (Sahay, 2015: 1). Ülkemizde de görebileceğimiz gibi birçok devlet bürokrasisi işlemi gerektiren işlemler, e-devlet sistemi üzerinden internet aracılığı ile gerçekleştirilmektedir. İnternet ve teknolojik araç kullanımı minimum olan bireyler de e-vatandaş olmaya zorlanmaktadır.

Antik Yunan şehir devletlerinde ortaya çıkan ve görevlerle birlikte haklar da verilen bir kavram olan vatandaş için bu girişimler hayat kolaylaştırmaktadır. Fakat bunun yanında bir vatandaşın internet aracılığıyla sanal olarak dünya çapında hareket edebildiği netizenler için ise verilen hizmetlerin sorumluluğunu yüklenmek anlamını taşımaktadır. Tüm netizenler bir milletin vatandaşıdır, ancak dünya nüfusunun büyük bir kısmının internet olanağı olmadığı için tüm vatandaşlar netizen değildir. Netizenler siber uzayı kamusal alanın bir uzantısı ve sivil katılım için bir alan olarak gördüğünden, bu platformun kötü amaçlarla kullanılmamasını sağlamak netizenlerin bir sorumluluğu olarak görülmektedir (Sahay, 2015: 3).

Bu durum, internet kullanıcılarının gelecek nesiller için daha güvenli bir internet ortamı hazırlaması konusunda sorumlu tutulabileceklerini belirtmektedir. Ancak internet ortamının düzenlenmesi ve daha güvenli bir hâle getirilmesi için vatandaşları netizen olmaya davet eden hükûmetlerin ve düzenleme kurum ve kuruIuşlarının sorumluluğu çok daha fazladır. İnternet vatandaşlığına geçme durumu son derece hızlı bir şekilde meydana gelirken internet ortamlarında işlenen suçlarla ilgili düzenlemeler bu hızın gerisinde kalmaktadır. Ülkemizde 5651 sayılı "İnternet Ortamında Yapılan Yayınların Düzenlenmesi ve Bu Yayınlar Yoluyla İşlenen Suçlarla Mücadele Edilmesi Hakkında Kanun" 04.05.2007 tarihinde kabul edilmiş ve bu kanun 31.07.2020 tarihinde düzenlenme yoluna gidilmiştir. Bu kanunun düzenlenmiş son hâli incelendiğinde Türk Ceza Kanunu'nda suç olarak nitelen eylemlerin aslında günlük ve gerçek hayatta işlenen ve artık internet dolayımlı araçlar ile işlenmeye devam edilen suçlara yer verdiği görülecektir. Internetin ortaya çıkması ve beraberinde getirdiği suçlar ile ilgili yeterli bir düzenleme bulunmamaktadır. Var olan düzenlemeler ise yer sağlayıcılara yaptırımı öngörmekte kullanıcıları eylemlerinden dolayı sorumlu tutmamaktadır. Hâlbuki internetin dünya geneline yayılması ve ülkemizde de yoğun kullanılmaya başlanması ile birlikte daha önce yapılamayan ve internet ortamının getirisi olan çeşitli yasal olmayan eylemler bulunmaktadır. 


\section{Anomi Kavramını Yeniden Düşünmek: Dijital Anomi (Dijitanomi)}

Dijitalleşmenin artması ile birlikte artık sosyolojinin başlangıcından beri kullanmış olduğu kavramların gözden geçirilerek bir sorguya tabi tutulması ve tekrardan ele alınması gerekli görülmektedir. İnternet araştırmaları alanı üzerine yapılan çalışmalar ise böyle bir gereklilikten doğmaktadır (Orton-Johnson ve Prior, 2013: 1).

Toplumdaki düzen ve ilerleme durumuna kuralların ve normların yetişememesi durumu anomiyi doğurmaktadır. Gerçek dünya ve dijital dünya arasındaki ilişki bu ikilinin bazen birbirini sınırladığı, bazen çatıştı̆̆, bazen yoğunlaşmış ortaklıklara girdiği etkileşimlere sahne olmaktadır. Her ne kadar fiziksel dünyamıza paralel olarak dijital ortamlarda var olsak ve eylemlerimizi sürdürsek de gerçek yaşant-mızdaki kurallar bu alanda gerçekleşen kimi etkinlikleri kapsamamaktadır. İnternet, kullanıcıları tarafindan her türlü amaca ulaşmak için sağlanan bir araç olarak değerlendirilmekte ve bu bağlamda kullanılmaktadır. Teknolojinin hızlı gelişimine yetiştirilemeyen internet düzenlemeleri de "dijitanomi"ye neden olmaktadır.

Schmidt ve Cohen, interneti dünyanın en büyük kontrolsüz alanı olarak tanımlamakta ve yukarıdan aşağı kontrollerdeki noksanlığın çevrim içi dolandırıcılık, zorbalık kampanyaları, nefret gruplarının oluşumu ve terörist sohbet odaları gibi sonuçlara neden olabileceğine dikkat çekmektedirler. Her dakika milyonlarca kullanıcı, bildiğimiz manada karasal yasalarla sınırlandırılmamış bir çevrim içi dünyada görülmemiş miktarda dijital içerik yaratmakta ve aynı zamanda bu dijital içerikleri tüketmektedir (Schmidt ve Cohen, 2013: 1).

Internetin hızlı bir biçimde hayatımıza dâhil olması ve birçok faaliyetin burada gerçekleştirilebilmesi, bunları sağlamak için gerekli kuralların ve kanunların hazırlanmasına firsat verilmeden meydana gelmiştir. Dijital ortamlara geçiş, planlanmış, tasarlanmış ve doğabilecek aksaklıkları giderecek düzenlemelerin hazırlandığı bir zeminde oluşmamıştır.

Fiziksel varlığımızı sürdürdüğümüz dünyadaki yaşantımızı düzenleyen kurallar ve yasalar, internet dolayımlı gelişmelerin hızlı ilerleyişi karşısında yavaş kalmıştır. Bu ortamlarda bulunan kullanıcılar, faaliyetlerini kuralsız bir alanda yürütmekte ve normal hayatta suç teşkil edebilecek eylemlerini herhangi bir yaptırıma tabi tutulmadan gerçekleştirebilmektedirler. Dijital ortamlara uyarlanmamış veya internet özelinde oluşturulmamış kurallar, faaliyetlerin kontrol edilememesine dolayısıyla da düzensizliğe zemin hazırlamaktadır.

Dijitalleşme, bilgiyi dijital teknolojiler aracılığıyla kolayca erişilebilen bilgiye dönüştürme etkisine sahiptir (Lupton, 2015: 21). Bu etki, insanların bedenlerini istediklerini elde etmek için hareket ettirmesine gerek kalmadan dijital ortamdaki 
sayısal bedenlenişleriyle kitap, haber, dizi, film, müzik gibi tüm ürünlere erişmesini sağlamaktadır. İnternet ortamında var olan bu ürünlere erişim, kimi sitelerde ücretli olabildiği gibi kiminde de yasak olmasına rağmen kaçak şekilde elde edilebilmektedir. Gündelik hayatımızda bir bedel karşılığında sahip olabileceğimiz ürünler internet ortamındaki kuralsızlıktan kaynaklı yasa dışı olarak elde edilebilmektedir. Nesnelerin sayısallaştırılmış kodlara dönüştürülmesi ve bunların denetimindeki eksiklikler dijital ortamlarda anominin doğmasını tetiklemiştir.

Internet öncesi dönemlerde bireyler; kitaplar, filmler, radyo ve televizyon programları gibi geleneksel medya ile ilişki kurabilseler dahi bu ilişki belirli bir seviyeye kadar çıkabilmekteydi. Dijital medyanın gelişimi etkileşimi farklı boyutlara taşımıştır. Geçmişte insanlar bu medya hizmetlerini almak için belli bir ödeme yapmak zorunda kalmaktaydılar. Bugün hâlâ bu durum geçerli olsa bile internetin getirdiği olanaklar kişilerin bu hizmetlerin daha fazlasına hiçbir ücret ödemeden sahip olabilmesinin önünü açmıştır. Kullanıcıların ödediği tek bedel, bilgisayar tabanlı bir akıllı cihaza ve internete sahip olmak için ödediği erişim bedelidir. Bu ikilinin bir araya gelmesi kullanıcıyı neredeyse sonsuz bir erişim imkânına sokmaktadır. Kendi dilinde veya farklı dillerde binlerce pdf kitap, dizi ve film izleyebileceği ve indirebileceği siteler, müzik dinleyebileceği ve indirebileceği platformlar, pornografi, bahis ve birçok yasaklı içerikler isteyenler tarafindan ulaşılabilir konumdadır. Bağlı bulunan ülkenin bu tarz sitelere erişimi engellemesi durumunda dahi farklı uygulamalar (VPN, DNS ayarları değişimi vb.) aracılığıyla kullanıcılar yasakları aşabilmektedir. Bir sitenin kapanması erişimin önünü kesememekte, ortamın sonsuz genişliği farklı site ve uygulamalar ile tekrar bu içeriklere ulaşmayı mümkün kılmaktadır.

İnternet aynı zamanda yaşayan bir arşivdir. Bu arşiv; verileri üretmekte, depolamakta, dağıtmakta ve iletmektedir (Smith, 2013). Dijital ortamlardaki faaliyetler her zaman öngörülebilir, yönetilebilir veya düzenli değildir. Bu arşivlerin içeriğinde denetim boşluğundan faydalanıp legal olmayan ürünlerin paylaşılması ve dağıtıIması söz konusudur. Buradaki içerikler isteyen kişilerin kullanımına açılmakta ve arayanlar tarafindan bulunabilir hâle getirilmektedir. Böylelikle ani gelişmeler ve değişikliklerin tetiklediği normlardan ve yaptırımlardan yoksun bir ortam dijital anomiyi ortaya çıkarmaktadır.

Bulunduğumuz noktadan biraz geriye doğru baktığımızda internet ortamında cevaplanması gereken bazı soruların olduğu görülmektedir. Internet ortamı ve onun kullanıcılarının etkinliklerinin tamamıla değil kısmen düzenlenmiş olduğu söylenebilmektedir. İnternet ortamındaki bu düzenleme yokluğunun "dijitanomi” olarak adlandıracağımız bir durumu meydana getirdiği düşünülmektedir. 
Hem günümüze daha yakın bir dönem olan Temmuz 2020 yılında yasalaşan sosyal medya düzenlemesinde hem de daha önce 2007 yılında yayımlanan 5651 sayılı Internet Ortamında Yapılan Yayınların Düzenlenmesi ve Bu Yayınlar Yoluyla İşlenen Suçlarla Mücadele Edilmesi Hakkında Kanun'nda görebileceğimiz gibi gerçek hayatta gerçekleştirilen suçların internet dolayımı ile işlenmesine yönelik düzenlemeler bulunmaktadır. Fakat internet ve dijital toplumun beraberinde getirdiği yasa dışı faaliyetlere yönelik bir düzenleme bulunmamakta ve buna bağlı olarak kullanıcıların yaptığı çoğu faaliyetin yasal olup olmadığı hakkında bilgisinin bulunmadığı düşünülmektedir.

2007 yılındaki düzenlemede konumuz bağlamında müstehcenlik ve kumar oynanmasına ilişkin maddeler bulunmaktadır. Ayrıca, içerik sebebiyle hakları ihlal edilenler talepte bulunarak ilgili içeriklerin yayından çıkarılmasını talep edebilmektedir. 2020 yılındaki düzenlemelerde ise sosyal medya üzerinden yapılan yayınlar, sosyal ağ sitelerinin temsilci bulundurması ve bunlara uyulmayan durumlar için çeşitli müeyyideler belirlenmiştir. Yapılan kanunsuz yayınlar ve içerik dağıtımına yönelik durumlarda yer sağlayıcıları için veya bunları izleyen, indirip sahip olan kullanıcılar için bir düzenleme söz konusu değildir. İçerik paylaşan ve yayanlar rahat bir biçimde bu faaliyetlerini sürdürmekte, diğer kullanıcılar da benzer kolaylıkla herhangi bir yaptırıma maruz kalmaksızın içeriğe ulaşabilmektedirler. Kimi engeller olsa da hem yayınlayanlar hem de kullanıcılar tarafindan bu engeller rahat biçimde farklı yollar kullanılarak aşılabilmektedir.

5846 sayılı "Fikir ve Sanat Eserleri Kanunu" da fiziksel hayatımızın sürdüğü alanlarda bulunan eser, eser sahibi ve onun maddi, manevi hakları tanımlanmıştır. Çoğaltma, yayma ve umuma iletişim hakkında sınırlar belirlenmiştir. Ancak bu durum, dijital ortamlarda etkisini gösterememekte, istifade edilen boşluklardan haklar ihlal edilebilmektedir. Bugün birçok web sitesinde veya sosyal medyada açılan hesaplarda internet ortamındaki kuralsızlıktan kaynaklandığı düşünülen hak sahiplerini göz ardı ederek suç teşkil eden yazılı ve görsel materyal paylaşılmaktadır.

\section{Yöntem}

Yöntem ile ilgili bilgilere geçmeden önce çalışmanın problemi ve çalışma hipotezlerine değinmenin önemli olduğu düşünülmektedir.

Sanayi devriminin ardından yaşanan hızlı teknolojik değişim ve dönüşümler sosyokültürel yapıda, yaşayış biçimlerinde ve hayatın birçok noktasında köklü değişiklikler meydana getirmiştir. Bu süreci yaşayan bireyler değişim ve dönüşümlerin çok hızlı gerçekleşmesi nedeniyle bazı alanlarda bu değişim ve dönüşümlere ayak 
uyduramamışlardır. Buna benzer bir şekilde içinde var olduğumuzu düşünebileceğimiz bilgi toplumunda internet ortamında gerçekleşen değişim ve dönüşümleri bireylerin çoğu zaman takip edemediği, yasal düzenlemelerin de bu durumları ivedi bir şekilde belirleyemeyerek kullanıcıları yeterince uyaramadığı ve onlar üzerinde yaptırım güçlerinin bu nedenle zayıf kaldığı düşünülmektedir. Çalışmanın problemi; bu tür durumların sebep olabileceği kargaşa, belirsizlik durumları ve etik dışı sorunların çözümsüzlüğe terk edilmiş olmasıdır. Bu ana problemin çözümlenmesine katkı sağlamaya yönelik olarak gerçekleştirilen çalışmanın hipotezleri aşağıda yer almaktadır:

H1: Dijital-sanal alanlarda varlık gösteren bireylerin, gerçekleştirdiği etkinlikler, teknoIojinin hızına ulaşamayan yasal düzenlemelerin eksikliği nedeniyle bir anomi durumuna yol açmaktadır.

H2: Dijital-sanal alanlardaki etkinlikleri düzenleyen belli yasalar olsa da bunlar internet ortamının hızına yetişememekte ve kapsayıcı olamadığından dolayı bir kuralsızlık ve normsuzluk hâli yaşanmaktadır.

H3: İnternet kullanıcıları internet dolayımlı araçlarla gerçekleştirdikleri etkinliklerin yasal veya yasa dışı olduğunun yeterince farkında değildir.

H4: Internet kullanıcıları gerçekleştirdiği kimi etkinliklerin yasal olmadığını bildiği hâlde bu etkinlikleri gerçekleştirmeye devam etmektedir.

H5: İnternet kullanıcıları gerçekleştirdiği kimi etkinliklerin etik olmadığını bildiği hâlde bu etkinlikleri gerçekleştirmeye devam etmektedir.

Çalışmada nicel araştırma yöntemi tercih edilmiş, nicel araştırma deseni olan betimsel tarama içerisinde yer alan anket tekniği kullanılmıştır. Betimsel tarama, geçmişte meydana gelmiş veya hâlihazırda var olan bir durumu bulunduğu biçimde tespit etmeye ve kayıt altına almaya çalışan araştırma modeline verilen isimdir. Bu modelde bir çalışmaya konu olan birey, nesne veya olay kendi değişkenleri içinde ve olduğu şekilde açıklanmaya çalışılır. Araştırılan durum, olgu veya olaylar herhangi bir biçimde değişikliğe uğratılmamaktadır. Bilinmek istenen durum orada beklemektedir. Amaç, bilinmek istenen durumu uygun bir şekilde gözlemleyip belgeleyebilmektir (Karasar, 2016: 109).

Durkheim ve Merton'un fiziksel yaşamımızda var olduğunu belirttiği anominin dijital ortamlarda da ortaya çıktığı düşüncesinin saptanabilmesi için anket soruları oluşturulmuştur. İnternet ortamında gerçekleşen faaliyetleri düzenleyen çalışmaların teknolojinin hızına yetişemediği ve yaptırımların caydırıcılığının bulunmadığı internet dolayımlı ortamlarda vakitlerini geçiren kullanıcıların, bu eylemlerini kolaylaştıracak 
araçlarla bilinçli veya bilinçsiz faaliyetlerinin dijital anomiye neden olup olmadığı ölçümlenmeye çalışılmıştır. Bu amaca ulaşmak adına kullanıcıların ücretli içeriklere ve ürünlere hangi yollarla ulaştğını ve kullanım pratiklerinin yasal durumları ile ilgili bilgi düzeylerini analiz etmeyi kolaylaştıracak bir metodoloji belirlenmiştir.

Araştırmanın evreni oldukça geniş olduğundan tesadüfi örnekleme türlerinden kolayda örnekleme kullanılmıştır. Evren büyüklüğünün 100 milyon ve üzeri olduğu durumlarda yüzde 95 güven düzeyinde 384 kişiye ulaşmanın yeterli olduğu bilgisinden hareketle (Yazıcıoğlu ve Erdoğan, 2004: 50), araştırmada en az 384 kişiye ulaşmak hedeflenmiştir.

\subsection{Veri Toplama Süreci}

Araştırmanın evreni, internet kullanıcılarıdır. Sınırlandırmaya gitme açısından ìstanbul ilinde ikamet eden TÜik'in (2018) yaptığı araştirmada interneti en yoğun kullandığı belirlenen 18-24 yaş aralığında yer alan lisans öğrencisi olan internet kullanıcıları örneklem olarak seçilmiştir. İnternet kullanım pratiklerinin ortaya çıkardığı düşünülen "dijital anomi" durumunun saptanmasına yönelik verilerin elde edilebilmesi için "tarama modeli" kullanılmıştır.

Araştırma kapsamında hedef kitleden veri toplayabilmek amacıyla bir anket formu oluşturulmuştur. Anket formu 2 bölüm ve toplamda 13 maddeden oluşmaktadır. Çalışmanın anket formunun ilk bölümünde katılımcıların demografik özelliklerini (yaş, cinsiyet, eğitim durumu) belirlemeye yönelik sorular bulunmaktadır. Bunun yanında ikinci bölümde ise katılımcıların konumuz bağlamındaki alanlarda internet kullanım pratiklerini belirlemeye yönelik sorular yer almaktadır.

Araştırma sürecine geçilmeden önce, alanda uzman kişilerden alınan görüş ile şekillendirilen anket formu ile Aralık 2021-Ocak 2021 tarihleri arasında 82 kişinin katılımıyla bir ön test gerçekleştirilmiş, ön test verilerinden yararlanılarak anket formu yeniden gözden geçirilmiş ve gerekli düzenlemelerin ardından form son hâlini almıştır. Anket formu, tesadüfï örnekleme türlerinden kolayda örnekleme yoluyla Ocak 2021-Şubat 2021 tarihleri arasında toplamda 393 adet olarak dijital ortamdan dağıtılmış (anket formu "Google formlar" uygulaması üzerinden dağıtılmıştır) ve yanıtlanan anket formlarının 393'ü değerlendirmeye alınmıştır.

\section{Verilerin Analizi}

Anketten elde edilen veriler SPSS 22.0 paket programına aktarılmış ve değişken türlerine uygun olarak kodlanmıştır. Toplanan veriler, araştırma problemleri dikkate alınarak analiz edilmiştir. Bu kapsamda internet kullanım pratiklerine ilişkin veriler betimsel istatistik kapsamında ele alınarak yüzdesel analizleri yapılmıştır. 
Betimsel istatistikler; verileri düzenlemek, sunmak ve analiz etmek için kullanılan sayısal ve grafiksel teknikleri barındırmaktadır (Fisher ve Marshall, 2008: 95). Betimsel istatistikler, genellikle merkezi eğilimin ölçüsü olarak adlandırılan bir puan dağılımının orta noktasını ve dağılım veya varyans olarak bilinen puanların yayılmasını tanımlamayı amaçlamaktadır (2008: 93). Bu sebeple çalışmada elde edilen verilerin özetlenmesi ve araştırma sonuçlarının yorumlanması adına bu teknik kullanılmıştır. Belli özellikleri taşıyan veya bir grubun üyesi olan elemanların (denek) sayısı biçiminde tanımlanabilen frekans dağılımı tablolarda gösterilmiştir. Ayrıca bütünün belirli bir bölümünün, bütünün 100 biriminin ne kadarını meydana getirdiğini gösteren bir indeks (Tan, 2016: 7) şeklinde tanımlanabilecek yüzde analizi sonuçları da tabloya eklenmiştir.

\subsection{Bulgular}

Internet kullanıcılarının dijital anomi durumunu ortaya koyduğunu düşündüğümüz kullanım pratiklerini incelemeye yönelik çalışmanın bulguları aşağıda sunulmuştur.

\subsubsection{Katılımcıların cinsiyet ve eğitim durumları}

Tablo 1. 18-24 Yaş Aralığında Yer Alan ve Anketi Dolduran Katılımcıların Demografik Özellikleri

\begin{tabular}{|l|l|c|c|}
\hline \multicolumn{2}{|c|}{} & N & $\%$ \\
\hline \multirow{3}{*}{ Cinsiyet } & Kadın & 213 & 54,19 \\
\cline { 2 - 4 } & Erkek & 180 & 45,81 \\
\hline \multirow{2}{*}{ Eğitim Durumu } & Lisans & 384 & 98 \\
\cline { 2 - 4 } & Yüksek Lisans & 8 & 2 \\
\hline
\end{tabular}

\subsection{2. İnternet içeriklerine ulaşmak için kullandığınız dijital medya araçlarını işaretleyiniz.}

Cevaplar Tablo 2'de belirtilmiştir.

Tablo 2. İnternet İçeriklerine Ulaşmak için Kullanılan Dijital Medya Araçları Kullanım Durumu

\begin{tabular}{|c|c|c|}
\hline & N & $\%$ \\
\hline Masaüstü Bilgisayar & 130 & $\% 33,1$ \\
\hline Laptop & 273 & $\% 69,5$ \\
\hline Tablet & 129 & $\% 32,8$ \\
\hline Akıllı Televizyon & 240 & $\% 61,1$ \\
\hline Akıllı Telefon & 376 & $\% 95,7$ \\
\hline Toplam & 393 & - \\
\hline
\end{tabular}


Tabloda yer alan bilgilerde görüldüğü gibi internet içeriklerine ulaşmak adına en fazla kullanılan dijital aracın akıllı telefon olduğu görülmektedir. Bu durum, içeriklere ulaşımda en kolay ulaşılabilen ve taşınabilir aracın tercih edildiğini göstermektedir. Bunun yanında birçok ortamda, var olan dijital araçlar ile içeriklere ulaşıldığı görülmektedir.

\subsubsection{Internet üzerinden dizi veya film izler misiniz?}

Cevaplar Tablo 3'te belirtilmiştir.

Tablo 3. İnternet Üzerinden Dizi ve Film İzleme Durumu

\begin{tabular}{|c|c|c|}
\hline & $\mathrm{N}$ & $\%$ \\
\hline Evet & 382 & 97,7 \\
\hline Hayır & 9 & 2,3 \\
\hline Toplam & 391 & 100 \\
\hline
\end{tabular}

Tabloda yer alan bilgilerde görüldüğü gibi internet üzerinden dizi veya film izleme edimi bireyler tarafindan sık tercih edilmektedir. Geleneksel kitle iletişim araçlarının yanı sıra internet ortamının da izleme alışkanlıklarının sürdürüldüğü alanlardan biri olduğu görülmektedir. Akıllı televizyonların internet erişimi sağlaması, kullanıcı dostu cihazların geliştirilmesi ve bilgisayar, cep telefonu gibi ekranlarla çevrili olmamız içeriklere ulaşım kanallarını çeşitlendirmektedir. Bu durum internet yoğun medya kullanımını göstermesi açısından önemlidir.

\subsection{4. İnternet üzerinden dizi veya film indirir misiniz?}

Cevaplar Tablo 4'te belirtilmiştir.

Tablo 4. İnternet Üzerinden Dizi veya Film İzleme Durumu

\begin{tabular}{|c|c|c|}
\hline & $\mathrm{N}$ & $\%$ \\
\hline Evet & 209 & $\% 53,3$ \\
\hline Hayır & 183 & $\% 46,7$ \\
\hline Toplam & 392 & 100 \\
\hline
\end{tabular}

Tabloda yer alan bilgilerde görüldüğü gibi film ve dizi indirme durumu yoğun biçimde gerçekleşmektedir. Normal şartlarda yayın haklarını elinde bulunduran kanalların veya şirketlerin sahip olduğu diziler/filmler onların dışındaki kişiler tarafindan internet ortamında bulunan farklı sitelerde yayınlanabilmektedir. Bu durum da internet kullanıcılarının ücret karşılığında erişebileceği içeriğe denetimsiz ve kuralsız biçimde işletilen alanlardan bedelsiz şekilde erişebilmesine zemin hazırlamaktadır. Dizi ve filmlere internet üzerinden erişim sağlayıp onları indirmek, 
korsan bir faaliyet olarak düşünülebilmekle birlikte günümüz toplumunda oldukça normal olarak görülmeye başlanmıştır.

\subsubsection{Internet üzerinden spor müsabakaları izler misiniz? (Cevabınız hayır ise nedenini diğer seçeneğinde belirtiniz.)}

Cevaplar Tablo 5'te belirtilmiştir.

Tablo 5.Internet Üzerinden Spor Müsabakaları İzleme Durumu

\begin{tabular}{|c|c|c|}
\hline & $\mathrm{N}$ & $\%$ \\
\hline Evet & 324 & $\% 82,7$ \\
\hline Hayır & 25 & $\% 6,4$ \\
\hline Diğer & 43 & $\% 10,9$ \\
\hline Toplam & 392 & 100 \\
\hline
\end{tabular}

Tabloda yer alan bilgilerde görüldüğü gibi yine yayıncı kuruluşların üzerinden gelir elde ettiği spor müsabakalarını internetteki diğer kanallar aracılığıyla izlemek, yayıncı kuruluş açısından hak kaybı yaratmakta fakat bu durum içerik sağlayıcının internet adresine ulaşımını engelleme dışında izleyen kişiye bir yaptırım öngörmemektedir. İçerik sağlayıc kişi ise internet adresini değiştirerek yayın sağlamaya devam etmektedir. Yayın haklarını bir bedel karşılığında satın almış platform, bu yayını yasa dışı biçimde internet ortamında erişime açanlar nedeniyle mağduriyet yaşamaktadır. Hizmet, dijital alanda kullanıcılar tarafindan bedelsiz erişilebilir hâle getirilmektedir. Ayrıca, internet üzerinden spor müsabakalarını izlemeyi tercih etmeyenlere neden tercih etmediği ile ilgili diğer seçeneği sunulmuş ve katılımcılar ya ücretli platformlara üye olduğu için ya da spora ilgisi olmadığı için bunları takip etmediklerini belirtmektedirler.

7.1.6. İnternet üzerinden PDF, EPUB, MOBI veya benzer formatlarda kitap indirir misiniz?

Cevaplar Tablo 6'da belirtilmiştir.

Tablo 6. Internet Üzerinde Kitap İndirme Durumu

\begin{tabular}{|c|c|c|}
\hline & $\mathrm{N}$ & $\%$ \\
\hline Evet & 327 & $\% 83,6$ \\
\hline Hayır & 64 & $\% 16,4$ \\
\hline Toplam & 391 & 100 \\
\hline
\end{tabular}


Tabloda yer alan bilgiler dikkate alındığında internetten kitap indirmenin çok yoğun olduğu göze çarpmaktadır. Bu durum kitap indirmenin oldukça normal karşılandığının göstergesi olarak okunabilmektedir. Yayınevi ve yazarın fiziksel yaşamda korsan kitapla mücadelesinin yanında dijital ortamların getirdiği kopyalama ve yayma kolaylığı eserin haklarının korunmasını zorlaştırmaktadır. Dijital kopyalar ve bunlara yer sağlayan siteler, internet ortamının denetimsiz yapısından kolayca faydalanmaktadır. Fakat Fikir ve Sanat Eserleri Kanunu dikkate alındığında suç olarak sayılan durumların internet dolayımı ile gerçekleştirildiğinde ya bilgi eksikliği ya da düzenlemelerin yetersizliği nedeniyle çok normal olarak görüldüğü saptanabilmektedir.

\subsubsection{Internet üzerinden müzik indirir misiniz? (Cevabınız hayır ise nedenini diğer seçeneğinde belirtiniz.)}

Cevaplar Tablo 7'de belirtilmiştir.

Tablo 7. İnternet Üzerinden Müzik İndirme Durumu

\begin{tabular}{|c|c|c|}
\hline & N & $\%$ \\
\hline Evet & 271 & $\% 69,1$ \\
\hline Hayır & 81 & $\% 20,7$ \\
\hline Diğer & 41 & $\% 10,2$ \\
\hline Toplam & 393 & 100 \\
\hline
\end{tabular}

Tabloda yer alan bilgilerde görüldüğü gibi "evet" cevabı yoğun bir şekilde öne çıkmaktadır. Bir ürün olan müzik eserlerine, bedeli ödenmeden kolayca ulaşılabilmektedir. Bir üretim ve emeği içeren bu ürünlerin bu şekilde dağılımı bu iş ile gelirlerini sağlayan kişilerin hak kaybı yaşamasına neden olmaktadır. Sanatçı ve bağlı olduğu şirket, dijital ortamda eserlerin izinsiz yayılımı karşısında yetkin bir mücadele sergileyemediğinden dolayı, dijital ortamın kendi aktörleriyle iş birliği içerisine girmesine neden olmaktadır. Bu durum müzik indirmeyi tercih etmeyenlerin hangi yollardan bu hizmetlere ulaşth̆ına bakıldığında somutlaşmaktadır. Müzik indirmeyi tercih etmeyenlere neden tercih etmediği ile ilgili diğer seçeneği sunulmuş ve kathlımcılar bu hizmetlere çeşitli ücretli uygulamalar veya YouTube gibi platformlar aracılığı ile eriştiğinden dolayı indirme eylemini gerçekleştirmediğini belirtmişlerdir. Her ne kadar legal platformlar oluşturulsa da bedelsiz hizmet erişimi elde etmek isteyenler dijital ortamlardaki normların yetersizliğinden faydalanıp bu isteklerini gerçekleştirebilmektedirler. 
7.1.8. Internet üzerinden yasaklı sitelere (bahis sitesi, cinsel içerik sitesi, vikipedi gibi daha önce içeriği engellenmiş siteler vb.) erişim sağlar mısınız? (Yanıtınız "Evet" ise sitelere nasıl eriştiğinizi 3 veya 4 nolu seçeneklerde belirtiniz.)

Cevaplar Tablo 8'de belirtilmiştir.

Tablo 8: İnternet Üzerinden Yasaklı Sitelere Erişim Sağlama Durumu

\begin{tabular}{|c|c|c|}
\hline & $\mathrm{N}$ & $\%$ \\
\hline Evet & 281 & $\% 71,7$ \\
\hline Hayır & 109 & $\% 27,8$ \\
\hline VPN & 275 & $\% 70,2$ \\
\hline DNS & 194 & $\% 49,5$ \\
\hline Toplam & 390 & - \\
\hline
\end{tabular}

Tabloda yer alan bilgilerde görüldüğü gibi içeriği engellenen sitelere erişimi yasak olmasına rağmen bireyler tarafindan bir yolu bulunarak onlara erişim sağlanmaktadır. Belli denetim ve kontrol girişimleri, teknolojinin sunduğu imkânlarla aşımakta ve kullanıcılar engellemeleri kolaylıkla aşarak diledikleri içeriklere erişim sağlayabilmektedirler. Sonuçlar dikkate alındığında hedeflere ulaşma konusunda engellerin aşılmakta olduğu ve internet ortamına özgü bir anomi durumunun yaşandığı söylenebilmektedir.

\subsubsection{Internet aracılığıyla birden çok platformu (Netflix, Blu TV, Puhu TV, Be-} insport vb.) tek bir üyelik üzerinden izlemeye imkân tanıyan IP TV ile ilgili bilginiz var mı?

Cevaplar Tablo 9'da belirtilmiştir.

Tablo 9. IP TV Hakkında Bilgi Sahibi Olma Durumu

\begin{tabular}{|c|c|c|}
\hline & $\mathrm{N}$ & $\%$ \\
\hline Evet & 267 & $\% 68,5$ \\
\hline Hayır & 123 & $\% 31,5$ \\
\hline Toplam & 390 & 100 \\
\hline
\end{tabular}

Tabloda yer alan bilgilerde görüldüğü gibi kimi ülkelerde yasalarla suç sayılan birden çok platformu (Netflix, Blu TV, Puhu TV, beIN Sports vb.) tek bir üyelik üzerinden izlemeye imkân tanıyan IP TV erişimi hakkında katılımcıların çoğu bilgi sahibidir. İnternet kullanıcılarının içeriklere erişim noktasında var olan kaynakları ve gelişen teknolojileri bildiği görülmektedir. Bu durum, potansiyel olarak meşru kanallar yerine bedelsiz veya daha düşük ücretler karşılığından hizmet sunanlara yönlenebilme intimalini barındırmaktadır. 
7.1.10. Film-Dizi içerik sağlayıcı platformlara ve yayın platformlarına (Netflix, BluTv, Beinsport, D- Smart) ayrı üyelikler yerine IP TV üzerinden ulaşıyor musunuz?

Cevaplar Tablo 10'da belirtilmiştir.

Tablo 10. IP TV İçeriklerine Erişme Durumu

\begin{tabular}{|c|c|c|}
\hline & $\mathrm{N}$ & $\%$ \\
\hline Evet & 117 & $\% 29,8$ \\
\hline Hayır & 276 & $\% 70,2$ \\
\hline Toplam & 393 & 100 \\
\hline
\end{tabular}

Tabloda yer alan bilgilerde görüldüğü gibi içeriklere IP TV üzerinden ulaşan dikkate değer bir kullanıcı grubu bulunmaktadır. Yasal olmayan bir mecrayı kullanmanın dijital ortama özgü bir anomi durumu yarattğı söylenebilmektedir. Çünkü farklı ücretli platformların kendi kullanıcılarına sunduğu hizmetler bu içeriklerin tek bir kanalda toplandığı ve hak sahipleri yerine bu girişimlerde bulunanların kazanç elde ettiği bir durumu ortaya çıkarmaktadır.

7.1.11. İnternet üzerinden gerçekleştirdiğiniz etkinliklerin (film ve dizi izleme-indirme, müzik-video indirme, pdf kitap vb. indirme, yasaklı site ve içeriklere ulaşma) yasal olup olmadığı hakkında bilginiz var mı?

Cevaplar Tablo 11'de belirtilmiştir.

Tablo 11. Yasal Durum Hakkında Farkındalık Durumu

\begin{tabular}{|c|c|c|}
\hline & $\mathrm{N}$ & $\%$ \\
\hline Evet & 166 & $\% 42,5$ \\
\hline Hayır & 225 & $\% 57,5$ \\
\hline Toplam & 391 & 100 \\
\hline
\end{tabular}

Tabloda yer alan bilgilerde görüldüğü gibi internet üzerinden gerçekleştirdiği edimler hakkında bilgisi olanlar azınlıkta kalmaktadır. Bilgisi olmasına rağmen kendi haklı veya haksız gerekçeleri ile bu edimleri gerçekleştirenlerin amacına ulaşırken tüm araçları kullanma eğilimleri dijital anomi durumunu gözler önüne sermektedir. Diğer yandan yasal süreç ile ilgili bilgisi olmayan fakat bu etkinlikleri gerçekleştiren kullanıcıların durumu ise düzenleme yoksunluğuna bir kanıt niteliğindedir. Bilindiği gibi anomi durumu düzenleme yoksunluğunun çıktısı olarak değerlendirilmektedir. İnternet ortamındaki bu durum da dijital anomi olarak adlandırdığımız kendine özgü anomi durumunu meydana getirmektedir. 


\section{Sonuç}

İnternetin kullanımının oldukça yaygınlaşması bu konu hakkında çalışmaları çeşitlendirmiştir. Sanal-dijital olarak adlandırılabilen günümüz toplumu birçok etkinliği internet dolayımı ile gerçekleştirdiği için artık sanal-dijital toplum ile gerçek hayat ayrımında muğlaklaşmaların var olduğu söylenebilmektedir. Bu nedenle toplumun içinde yer aldığı durumların açıklanabilmesi için daha önce yapılan çalışmaların içinde bulunduğumuz duruma uyarlanabilmesinin mümkün ve gerekli olduğu düşünülmüştür. Bu kapsamda TÜik'in yaptı̆̆ çalışmada \%90,7 ile interneti en yoğun kullanan yaş aralığında olan lisans öğrencilerine nicel araştırma deseni olan betimsel tarama içerisinde bulunan anket tekniği uygulanmıştır. İnternet ortamında dağıtılan anketle kolayda örnekleme yoluyla veriler toplanmıştır ve bu alanlarda gerçekleştirilen faaliyetlerin hızına yetişemeyen yasal düzenlemelerin ve kullanıcıların bu konu hakkındaki bilgi oranlarının dijital anomiye yol açıp açmadığı ölçümlenmeye çalışılmıştır.

Çalışmamızda sorgulanan durumlardan bir tanesi meta olarak ücreti ödenerek de ulaşılabilecek içeriklerin ve hizmetlerin internete erişim ücreti ve cihaz satın alma maliyeti dışarıda tutulduğunda ücretsiz şekilde ulaşılması durumuna düzenlemelerle müdahale edilmemesi veya neden müdahale edilmediğidir. Bu noktada açık erişimin engellenemeyeceği savunması yapılabilirken diğer yönden ise yetişmiş bilgi ve iletişim teknolojileri uzmanının yetersizliği durumu düşünülebilmektedir. İnternet adresi erişim engeline takılan yasaklı siteler web adresindeki bir harfi ya da sayıyı değiştirerek siteye erişimi yeniden aktif hâle getirebilmektedir. Burada sorgulanması gereken ise bu durumun neden engellenemediğidir.

Çalışmada yöneltilen sorulardan elde edilen verilerin de gösterdiği gibi kullanıcıların büyük çoğunluğu internet dolayımlı ortamlardan telifli ürünlere ücretsiz biçimde erişebilmektedir. Dizi, film, kitap, müzik gibi eserlerin hem üreticisinin hem de bağlı bulunduğu şirketlerin yasal haklarının dijital ortamlardaki düzenleme yetersizlikleri sebebiyle ihlale açık olduğu görülmektedir. Bu ürünlere ücretsiz olarak erişim sağlamayı tercih etmeyenlerin nedenlerini ise ilgi alanlarına girmemesi ve/ veya farklı yollardan içeriklere ulaşması oluşturmaktadır. İnternet ortamının maddi olmayan yapısı, içeriklerin ve ürünlerin sunulduğu kaynakları kolaylıkla artırabilmekte ve yayılımı hızlanan telifli ürünlerin kontrolünü zorlaştırmaktadır. Kullanıcılar içeriklere ulaşmada çeşitli zorluklarla karşılaştı̆ında ise VPN kullanarak veya DNS ayarlarında değişiklikler yaparak erişimin önündeki engelleri aşmaktadırlar. Var olan yasal düzenlemeler bu şekilde aşılmakta, teknolojinin gelişimine normların yetişemediği görülmektedir. İnternet ortamına ürünlerin ve içeriklerin kimi kullanıcılar tarafindan yerleştirilme ve yine ağlardaki diğer kullanıcılar tarafindan da be- 
delsiz olarak elde edilme durumunun yoğunluğu, yasal düzenlemelerin eksikliğini ve var olanların da caydırıcılığının yetersizliğini göstermektedir. Dolayısıyla ilk iki hipotezimizde öne sürülen yasal düzenlemelerdeki boşluk ve bu boşluktan yararlanan kullanıcıların faaliyetlerinin dijital anomiyi doğurduğu söylenebilmektedir. Yine kullanıcıların gerçekleştirdikleri eylemlerin yasal ve etik boyutları hakkında bilgileri olup olmaması durumu ölçümlenmiştir. Kullanıcıların önemli bir kısmı gerçekleştirdiği eylemlerin yasal olup olmadığı hakkında bilgisi olmasına rağmen faaliyetlerini sürdürdüğünü, kimisi ise bilgisinin olmadığını belirtmektedir. Bu durum bize, dijital ortamlardaki normsuzluk hâlinin giderilmesi için mevcut yasaların daha bilinir hâle getirilmesi gerektiğini ve teknolojik ilerlemeleri yakalayacak şekilde de kanunların düzenlenmesi gerektiğini göstermektedir.

İçeriklere ücretsiz bir şekilde erişim, fikir ve eser sahiplerinin gelir imkânını minimuma düşürürken diğer yandan yasaklı sitelere erişim durumu, düzenleme ve bilgilendirmelerin yetersizliğini göstermektedir. Dijital dünyada gerçekleştirdiğimiz eylemlerimiz için ne tür sorumlulukların alınacağı ve yaptıklarımızın hesap verebilirliğini üstlenip üstlenemeyeceğimizin konuşulması önem arz etmektedir. Kullanıcıların legal olmayan biçimlerde ürünleri indirme ve içeriklere erişme durumunun "dijitanomi” olarak adlandırdığımız durumu destekler nitelikte olduğu görülmektedir. Belli yasalar olsa da bunlar internetin hızına yetişememekte, kapsayıcı olamadığından dolayı kuralsızlık ve normsuzluk hâli devam etmektedir. Daha kapsayıcı önemler alınarak telif sahibi kurumların ve kişilerin haklarının ihlal edilmesinin önüne geçmek için hem bireysel yönden bilinçlendirmeye gidilmesinin hem de olası ihlalleri engellemek adına yer sağlayıcılara ek olarak bunlara erişen kullanıcılara da yaptırımlar uygulanmasının önemli olduğu düşünülmektedir.

Sonuç olarak Durkheim ve Merton'un “anomi” kavramı bugün içinde bulunduğumuz internet dolayımlı toplum biçiminde var olan anomi durumlarını teşhis edebilmek için kullanılmış, çalışmanın sonucunda anket sorularından özellikle yasal durum hakkındaki farkındalık sorusuna verilen cevaplar (\%42,5 evet, \%57,5 hayır) neticesinde internet yoğun toplumda bir anomi durumunun var olduğu görülmüştür. Bu kanıya varılmasının nedeni, internet ortamında gerçekleştirilen etkinliklerin yasal olup olmamasının kullanıcının faaliyetlerini etkilememesidir. Yasal durum hakkında bilgisi olmayan kullanıcılar dikkate alındığında yasaların yetersizliği ya da yasalar hakkında bilgilendirmelerin yetersiz olduğu sonucuna varılmaktadır. Yasal durum hakkında bilgisi olan kullanıcıların faaliyetlerine devam etmesi ise anomi kavramı içerisinde değerlendirilebilmektedir. Tüm bu sonuçlar ışığında dijital ortama atıfı da içinde barındıran "dijitanomi" kavramsallaştırması ortaya konulmuştur. 


\section{Kaynaklar}

Castells, M. (1996). The Information Age: Economy, Society, and Culture: The Rise of the Network Society. Oxford: Blackwell Publishing.

Castells, M. (1997). The Information Age: Economy, Society, and Culture: The Power of Identity. Oxford: Blackwell Publishing.

Castells, M. (1998). The Information Age: Economy, Society, and Culture: End of Millennium. Oxford: Blackwell Publishing.

Durkheim, E. (1984). The Division of Labour in Society, London: The Macmillan Press Ltd. Durkheim, E. (2006). Sosyoloji Dersleri, Ali Berktay (Çev.), İstanbul: iletişim Yayıncılık.

Fisher, M. J., Marshall, A. P. (2009). Understanding Descriptive Statistics. Australian Critical Care, 22(2), 93-97.

Hacker, K. L., Dijk, J. A. (2000). Digital Democracy: Issues and Theory of Practice. London: SAGE Publications Ltd.

Hague, B. N., Loader, B. D. (1999). Digital Democracy: Discourse and Decision Making in the Information Age. London: Routledge.

Hauben, M., Hauben, R. (1998). Netizens: On the History and Impact of Usenet and the Internet, First Monday.

Hindman, M. (2009). The Myth of Digital Democracy. Princeton: Princeton University Press.

Inderbitzin, M. L., Bates, K. A., Gainey, R. R. (2016). Deviance and Social Control: A Sociological Perspective, California: Sage Publications Ltd.

Jaishankar, K. (2011). Cyber Criminology: Exploring Internet Crimes and Criminal Behavior. Florida: CRC Press.

Karakaya, í. (2012). Bilimsel Araştırma Yöntemleri. Abdurrahman Tanrı̈ğen (Ed.) Bilimsel Araştırma Yöntemleri. (s. 57-83). Ankara: Anı Yayıncılık.

Karasar, N. (2016). Bilimsel Araştirma Yöntemi: Kavramlar, İlkeler, Teknikler. Ankara: Nobel Akademik Yayıncılık.

Lindgren, S. (2017). Digital Media and Society, London: Sage Publications Ltd.

Lupton, D. (2015). Digital Sociology, New York: Routledge.

Lyon, D. (2001). Surveillance Society: Monitoring Everyday Life. Buckingham: Open University Press.

Marshall, G. (2005). Sosyoloji Sözlüğü, Ankara: Bilim ve Sanat Yayınları.

Merton, R. K. (1938). Social Structure and Anomie, American Sociological Review, 3(5), s.672-682.

Merton, R. K. (1968). Social Theory and Social Structure, New York: The Free Press.

Ofluoğlu, G., Büyükyılmaz, O. (2008). Yabancılaşmanın Teorik Gelişimi ve Tarihsel Süreç Içinde Farklı Alanlarda Görünümleri, Kamu-iş̧ Iş Hukuku ve İktisat Dergisi, s.113-144.

Orton-Johnson, K., Prior, N. (Ed.), (2013). Digital Sociology: Critical Perspectives, London: Palgrave Macmillan.

Papacharissi, Z. (2011). A Networked Self. Zizi Papacharissi (Ed.), A Networked Self: Identity, Community, and Culture on Social Network Sites. (304-319). New York: Routledge. 
Sahay, A. (2015). From Citizen to Netizen, Business Today in.

Sassen, S. (2017). Preface. Jessie Daniels, Karen Gregory, Tressie McMillan Cottom (Ed.), Digital Sociologies. (s. viii-ix). Bristol: Policy Press.

Schmidt, E., Cohen, J. (2013). The New Digital Age: Reshaping the Future of People, Nations and Business, New York: Alfred A. Knopf.

Schneck, P. (2010). Restricting Anti-Circumvention Devices. Sumit Ghosh, Elliot Turrini (Ed.), Cybercrimes: A Multidisciplinary Analysis. (s.73-95). Heidelberg: Springer.

Smith, M. (2013). Theses on the Philosophy of History: The Work of Research in the Age of Digital Searchability and Distributability. Journal of Visual Culture, 12(3), s.375-403.

Tan, Ş. (2016). SPSS ve Excel Uygulamalı Temel İstatistik-1. Ankara: Pegem Akademi. tuik.gov.tr, http://www.tuik.gov.tr/PreTablo.do?alt_id=1028, (Erişim Tarihi: 10.01.2021). Turkle, S. (1995). Life on the Screen: Identity in the Age of the Internet. New York: Touchstone.

Van Dijk, J. (1999). The Network Society: Social Aspects of New Media. London: Sage Publications Ltd.

Webster, F. (2006). Theories of the Information Society, New York: Routledge.

Yazıcıoğlu, Y., Erdoğan, S. (2004). SPSS Uygulamalı Bilimsel Araştırma Yöntemleri. Ankara: Detay Yayıncilık. 

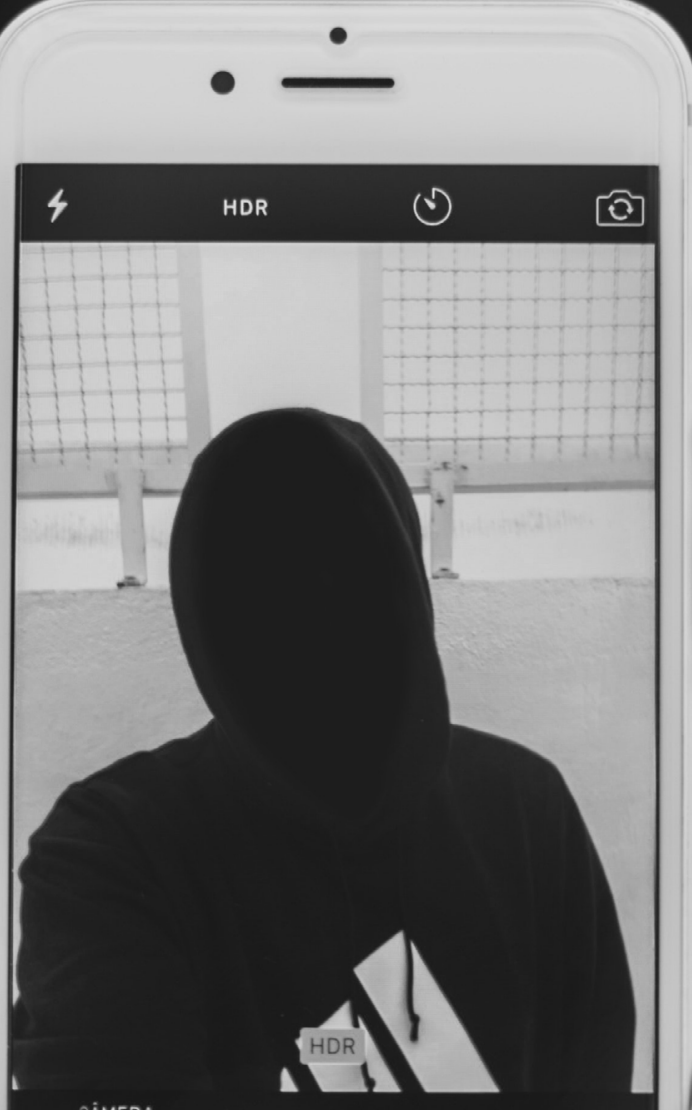

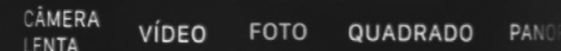

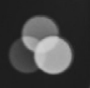

